UNITED STATES

DEPARTMENT OF THE INTERIOR

GEOLOGICAL SURVEY

WATER RESOURCES DIVISION

\title{
GENERALIZED \\ FLOOD-FREQUENCY ESTIMATES FOR \\ URBAN AREAS IN MISSOURI
}

By

E. E. GANN

Open-file report

Ro11a, Missouri

1971

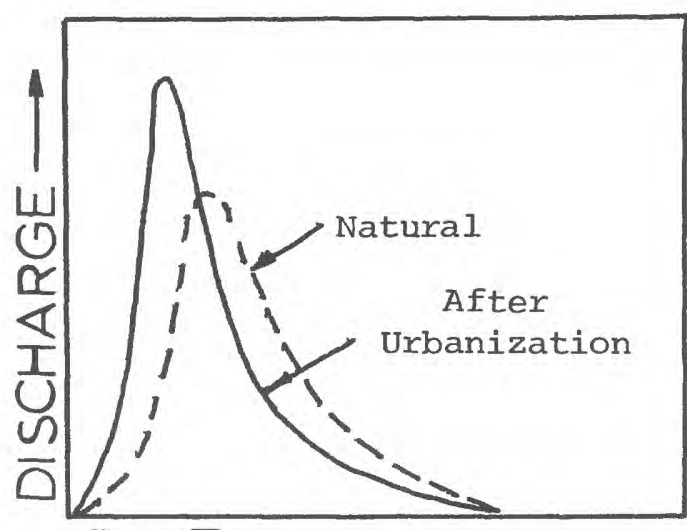

TIME

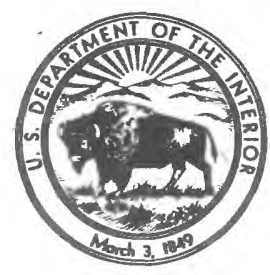




\author{
UNITES STATES \\ DEPARTMENT OF THE INTERIOR \\ GEOLOGICAL SURVEY \\ WATPER RESOURCES DIVISION
}

\title{
General1zed Flood-Frequency Estimates for \\ Urban Areas in Missouri
}

By E. E. Gann

Open-File Report

Rolla, Missourl

1971 
Abstract-_ 1

Introduction- 2

Method of analysis 4

Use of relations- 13

Limitations of relations- 14

References 17

\section{IIIUSTRATIONS}

Figure 1. Nomograph for solution of the equation,

$$
Q_{2.33}=72.3 \mathrm{~A} \cdot 719 \mathrm{~s} \cdot 330
$$

2. Effect of urbanization on mean annual flood for a 1-square-mile drainage area

(after Leopold, 1968)

3. Relation of floods in Missouri to the mean annual flood for selected degrees of basin imperviousness

TABLE

Table 1. Effect of urbanization on mean annual flood for three partially urbanized basins in Missouri- 


\title{
Generalized Flood-Frequency Estimates for \\ Urban Areas in Missouri
}

By E. E. Gann

\begin{abstract}
A method is presented for estimating flooci..frequency information for urban areas in Missouri. Flood-frecuency relations are presented which provide an estimate of the flood-peak discharge for floods with recurrence intervals from 2.33 to 100 years for basins with various degrees of existing or profected urban development. Drainage area sizes for which the relations are applicable range from 0.1 to 50 square miles.

These generalized relations will be useful to the urban planner and designer until more comprehensive studies are completed for the individual urban areas within the state. The relations will also be of use in the definition of flood-hazard areas in Missouri.
\end{abstract}


INTRODUCTION

Several investigators have examined the effects of urbanization on flood peaks in various sections of the United States. Included among these investigators are Carter, 1961, (Washington, D.C.); Wiitala, 1961 (Detroit, Mich.); Martens, 1966 (Charlotte, N.C.) - Wilson, 1966 (Jackson, Miss.); Epsey and others 1966 (Tex.); and Anderson, 1968 (Fairfax County, Va.).

These investigators generally have assumed that urbanization affec": "Ioods in two principal ways: (1) the construction of streets, sidewalks, parking lots, and buildings reduces the amount of infiltration for a given storm and results in a greater volume of storm runoff from an urban basin than from a natural (no arbanized) basin, (2) the construction of street and highway gutters, storm sewers, and improved stream channels increase the drainage efficiency of a basin and results in faster removal of floocivaters from the basin. The cumulative effect of the increased volume of storm runoff and the faster removal of floodwater results in higher flood-peak discharges in urban basins than in natural basins.

Urbanization also has been shown (James, 1965 and Anderson, 1968) to have a greater effect on low-order (more frequent) floods than on high-order (less frequent) floods. This lesser effect on high-order floods is attributed to the fact that high-order floods on a natural basin are more likely to occur when the basin is in a highly saturated condition resulting in 
relatively little infiltration and a greater proportion of storm runoff. Thus, the magnitude of the increase in flood-peak discharges due to urbanization depends on the original infiltration characteristics of the basin, the type and degree of urban development, and the frequency or average return period of the storm event.

The purpose of this report is to provide an estimate of the increase in flood-peak discharge due to urbanization so that for urban areas, engineers can design adequate drainage systems and water-related structures which will accomodate the higher flows safely, efficiently, and economically. Observations of flood runoff from urban areas have recently begun in Missouri, but generally these will need to be continued for several years before they will become a useful basis for flood-frequency estimation. A U.S. Geological Survey flood-data collection project, initiated. in the St. Louis Metropolitan area in 1967 in cooperation with the St. Louis Metropolitan Sewer District, is scheduled for completion in 1973. A similar project for St. Louis County, initiated in 1970 in cooperation with St. Louis County, is scheduled for completion in 1975. This report presents a highly generalized method of estimating flood-peak discharges for urban areas in Missouri which will be useful to the design engineer until more comprehensive 
and refined studies based upon these newly acquired data can be completed for individual urban areas.

Peak-discharge data for Missouri streams used in the preparation of this report were collected by the water Resources Division of the U.S. Geological Survey in cooperation with the Missouri Geological Survey and Water Resources, William C. Hayes, State Geologist and Director, and the Missouri State Highway Commission, Marvin J. Snider, chief engineer, succeed: " by Robert N. Hunter. The report was prepared in the Missouri district of the Water Resources Division, under the direction of Anthony Homyk, Jr., district chief.

\section{METHOD OF ANALYSIS}

Using a mul ple-regression analysis, Sandhaus and Skelton (1968) defined a relation for estimating the mean annual flood (recurrence intervä of 2.33 years) for natural streams in Missouri as

$$
2_{2.33}=^{72.3 A} A^{\cdot 719} S^{\cdot 330} \text {, }
$$

where

$Q_{2.33}$ is the mean annual flood, in cfs (cubic feet per second),

A is basin area, in square miles,

$S$ is average basin slope, in feet per mile, between points 10 and 85 percent of the total main stem distance upstream from the site. 
This equation was based on flood data for 208 natural sites in Missouri with drainage areas of 0.1 to 10,000 square miles and the standard error of estimate was 44.1 percent. A nomograph for solution of equation 1 is given in figure 1.

Leopold (1968) combined the results of seven studies made in different parts of the United States and, with necessary assumptions (including the assumption of areally complete development) summarized the results to show the effect of different degrees of urbanization on the mean annual flood for a one-square mile area (fig. 2). Figure 2 indicates, for example, that the mean annual flood for a one-square mile urban basin with 40 percent of the area impervious and 40 percent served by storm sewers will be approximately 2.5 times greater than for the same basin under natural conditions.

Although the ratios shown in figure 2 apply to a onesquare mile area, it is assumed that they also can be applied with little loss of accuracy to other sizes of urban basins within the range of 0.1 to 50 square miles. This assumption does not appear to be critical when one considers the assumptions and interpretations necessary in combining the seven studies (most of which were made on urban basins with 
DRAINAGE AREA, IN SQUARE MILES

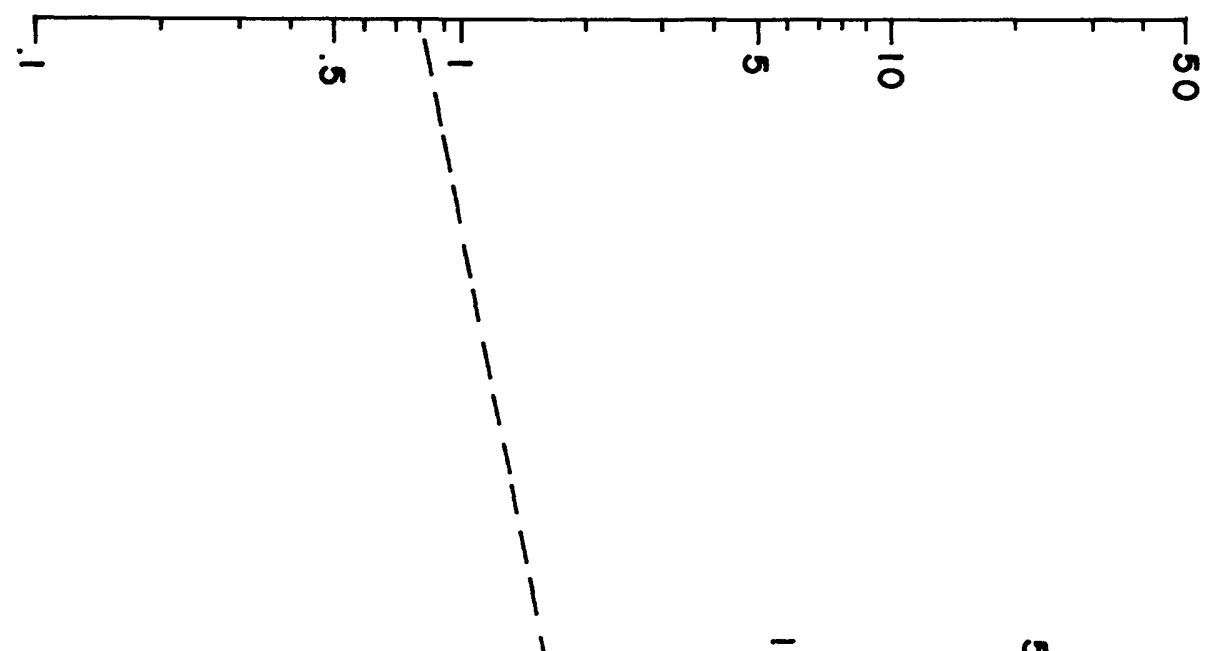

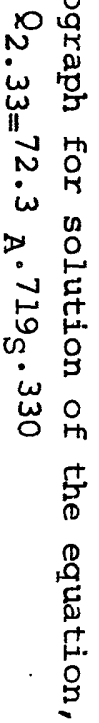
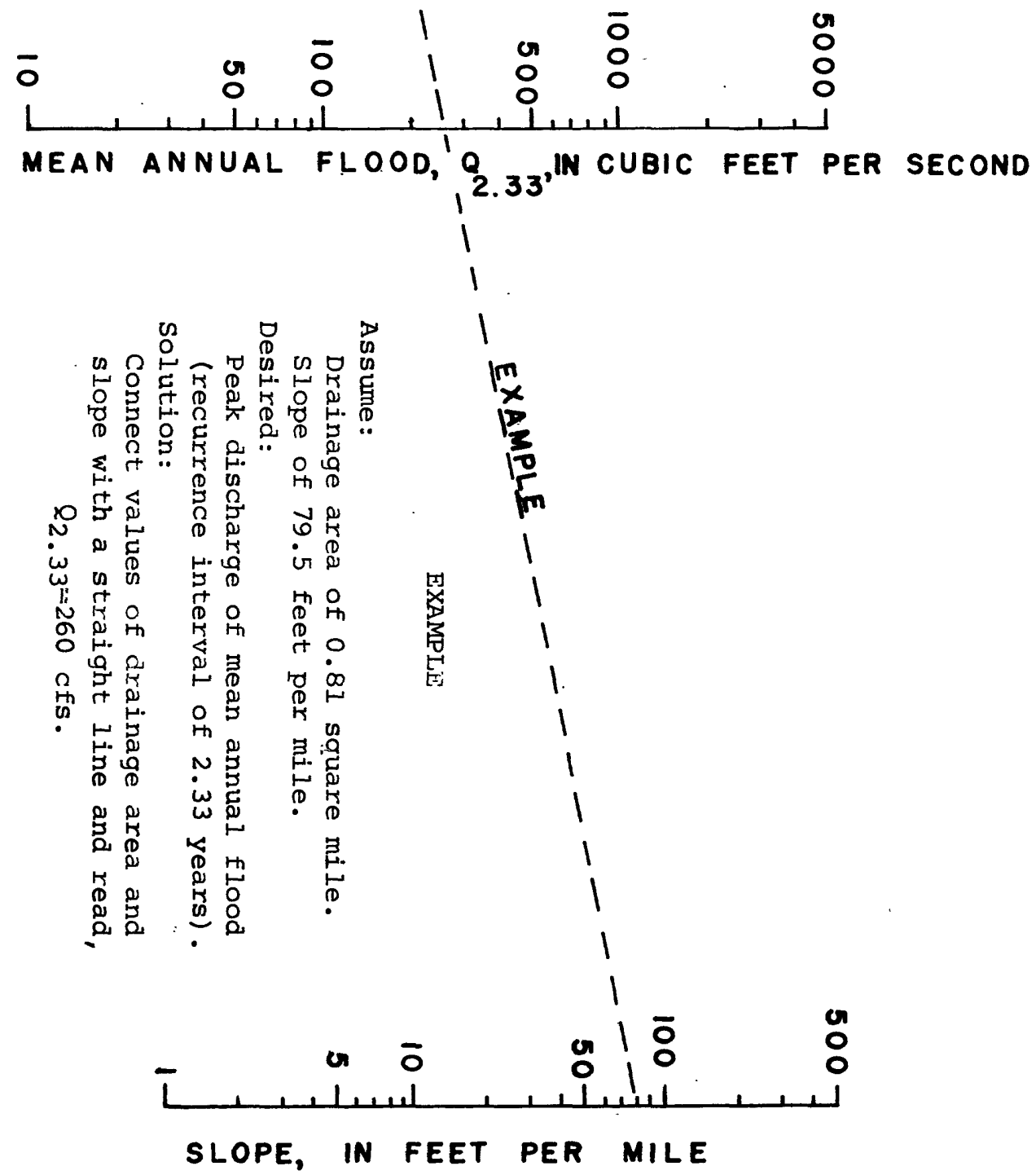

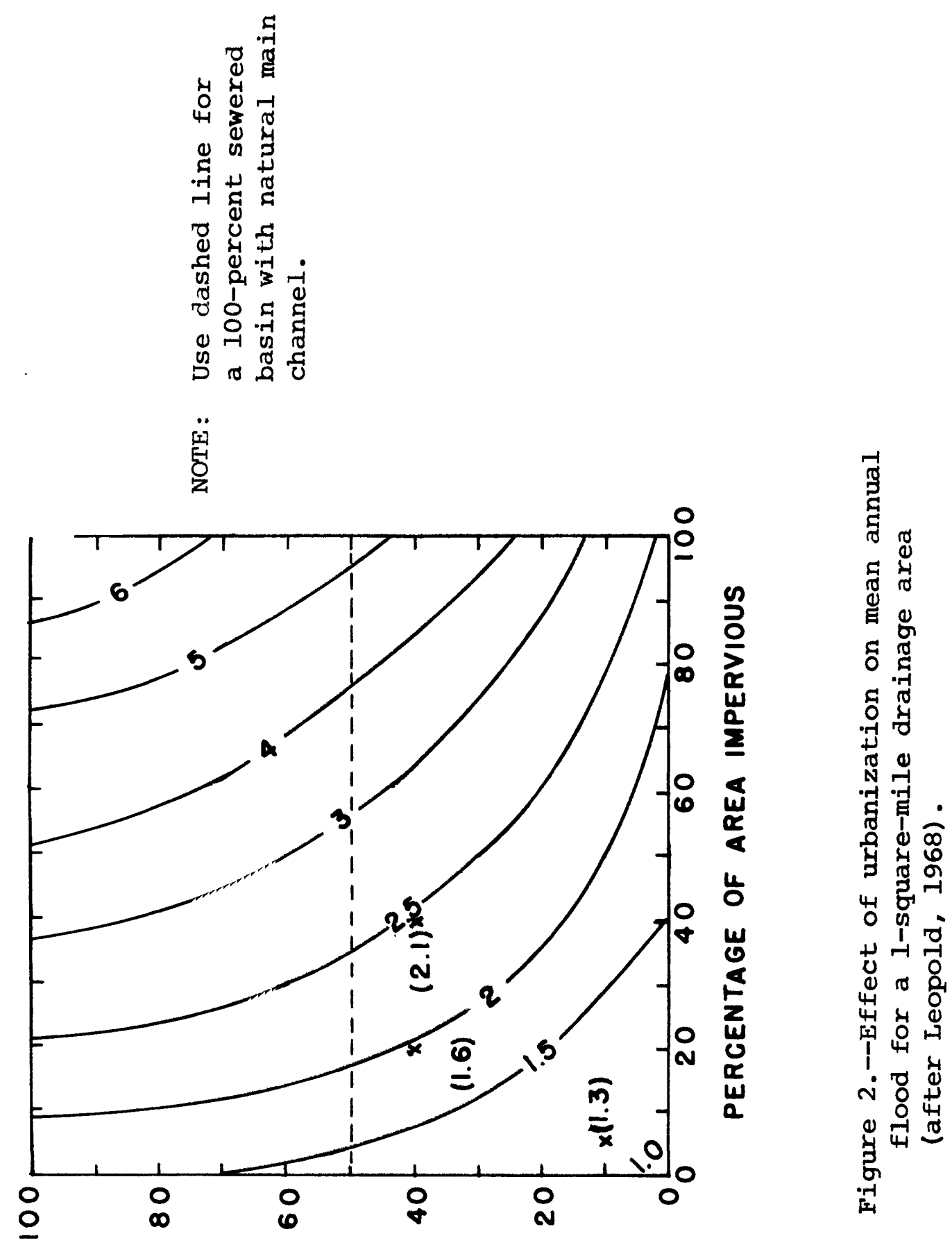

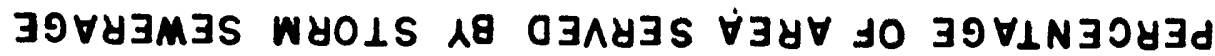


drainage areas within the range of 1 to 40 square miles) to define the relationship shown in figure 2. It is also noted in Anderson's study (1968, p. 24) that for the mean annual flood the ratio of flood-peak discharge after urbanization to flood-peak discharge before urbanization is only 10 percent less for an "average size" basin than for a "relatively small, steep" basin'.

It is further assumed that the relationship in figure 2 is applicable to Missouri. To support this assumption, limited data for three partially urbanized basins in Missouri were analyzed to yield the results shown in table 1.

Data from table 1 are plotted in figure 2 with the computed ratios shown in parenthesis. Although admittedly crude, this comparison indicates an acceptable level of agreement especially for basins with a limited degree of urban development. It is also noted that the seven studies used to define figure 2 include basins of diverse hydrologic and climatic conditions which support the applicability of figure 2 to Missouri.

Thus, by applying the appropriate ratio from figure 2 to equation, I (or fig. 1) an estimate of the mean annual flood for any expected degree of urbanization can be obtained for urban basins in Missouri. The problem now is to derive an expression which accounts for the effects of urbanization on high-order floods. 


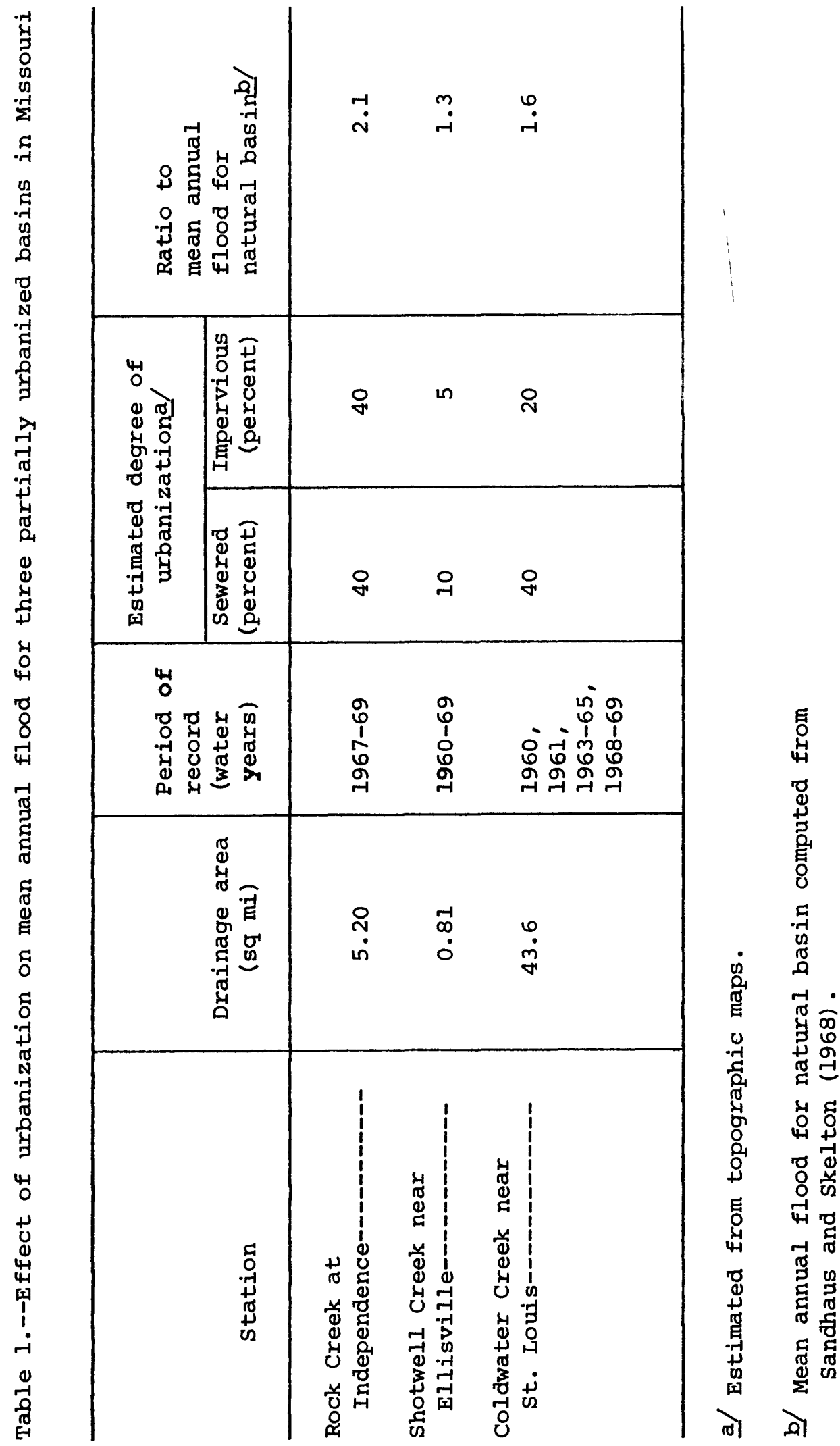


To account for the effects of urbanization on floods greater than the mean annual flood, a procedure introduced by Anderson (1968) was adapted to Missouri. First, floodfrequency curves for 106 natural streamflow sites in Missouri with drainage areas of 0.08 to 50 square miles were analyzed to vield the "natural" dimensionless frequency curve shown in igure 3. This generalized curve shows the ratio to the mean anmual flood of any selected flood up to a recurrence interva: of 100 years for natural basins. A log-Pearson Type III frequency distribution was assumed for the individual frequency curves in the analysis and these were extended to the 100-year recurrence interval. Median values for selected recurrence inten vals were computed and used to define the upper curve in figure 3. The following table summaxizes the results of the analysis this curve:

\begin{tabular}{cccc}
$\begin{array}{c}\text { Recurrence } \\
\text { interval, } \\
\text { in years }\end{array}$ & $\begin{array}{c}\text { Stations } \\
\text { used }\end{array}$ & $\begin{array}{c}\text { Ratio } \\
\text { range }\end{array}$ & $\begin{array}{c}\text { Ratio } \\
\text { median }\end{array}$ \\
\hline 2.33 & 106 & - & 1.00 \\
10 & 106 & $1.22-9.16$ & 2.58 \\
25 & 91 & $1.84-23.1$ & 3.49 \\
50 & 76 & $1.96-25.0$ & 4.39 \\
100 & 76 & $2.09-41.1$ & 5.06
\end{tabular}




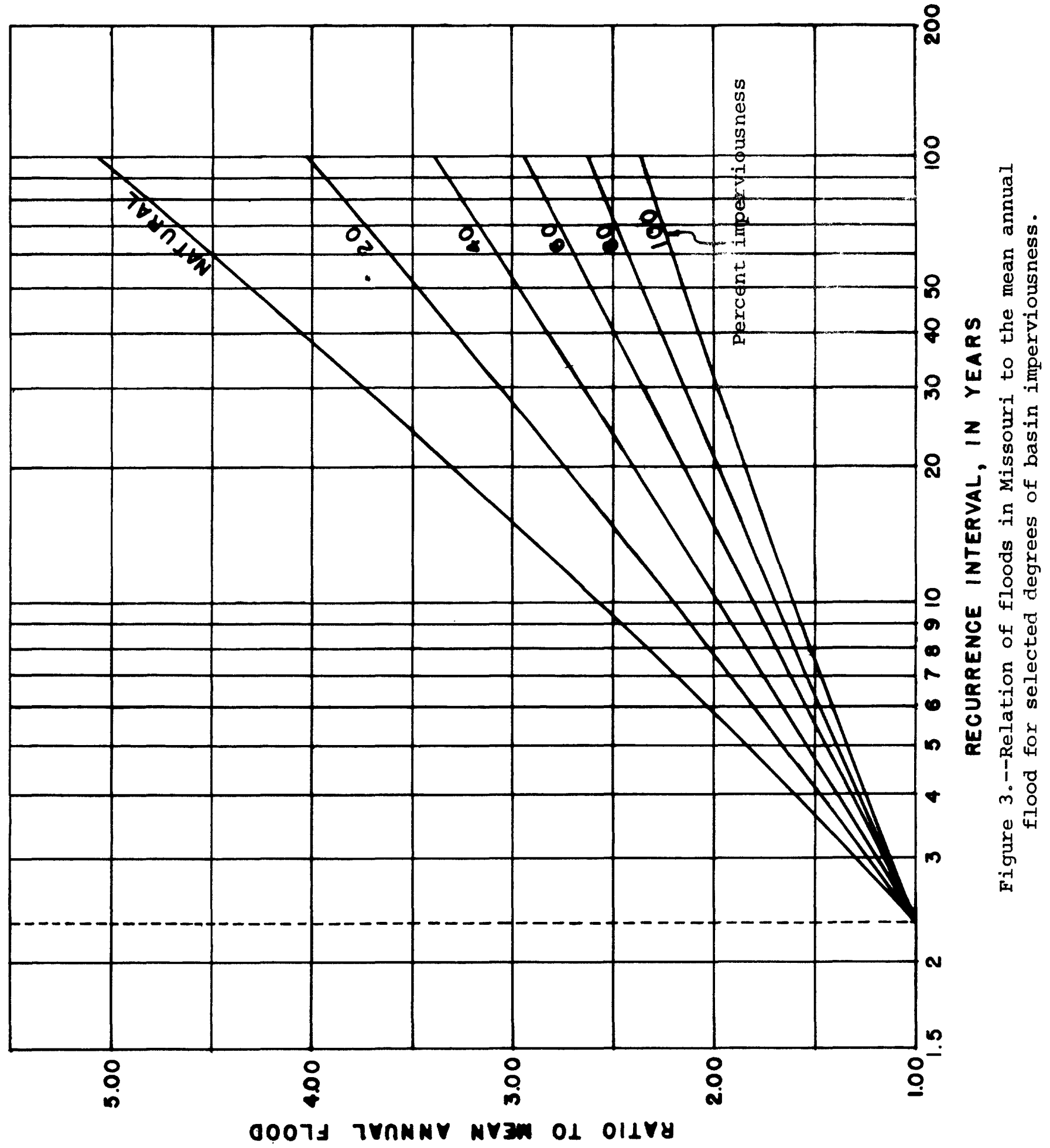


Following Anderson's procedure, it was then assumed that the shape of a dimensionless frequency curve for a 100-percent impervious basin approaches the shape of a dimensionless rainfallfrequency "elation. Using U.S. Weather Bureau rainfall-frequency relations (1955), the dimensionless frequency curve for a 100-percent impervious basin was defined for Missouri. This curve is shown as the lower curve in figure 3. The curves for othe: percentages of imperviousness in figure 3 were interpreted betwest the natural curve and the 100-percent impervious curve on the basis of the formula proposed by Anderson (1968, p. 21)

$$
R_{i}=\frac{R_{n}+.01 I\left(2.5 R_{100^{-R}}\right)}{1.00+.015 I}
$$

where

$R_{i}$ is the flood ratio for a given percent of imperviousness, I is the perceit of the basin covered with impervious surface, $R_{100}$ is the flood ratio for a 10 -percent impervious basin, and, $R_{n}$ is the flood ratio for a natural basin. Figure 3 supports James' conclusions (1965, p. 233) that an increase in urbanization (measured as an increase in imperviousness of the drainage basin) has less effect on high-order floods than on low-órder floods. 


\section{USE OF RELATIONS}

The relations presented in the analysis may be combined and summartzed as follows:

$$
Q_{X}=R_{1} R_{2} Q_{2} .33^{m 72.3} R_{1} R_{2} \cdot 719{ }_{S} \cdot 330,
$$

where

2x 1 s the magnitude of a flood of x-year recurrence interval, In cfs,

$R_{1}$ is the ratio of discharge after urbanization to discharge before urbantzation for the mean annual flood from figure 2, $R_{2}$ is the flood-frequency ratio from figure 3 , 22.33 is the magnitude of the mean annual flood in cfs, from equation 1 or figure 1 ,

A is basin area, in square miles, and, $\mathrm{S}$ is basin slope, in feet per mile (determined as the average slope, in feet per mile, between points 10 and 85 percent of the total main stem distance upstream from the site).

The following example 1llustrates the use of the presented relations. Assume that the peak discharge for the 100-year flood 1s, deslred at the Shotwell Creek near Ellisville gaging station for a profected degree of development of 40 percent imperviousness and 40 percent of the area served by storm sewers. 
1. From a topographic map of the area, determine the arainage area to be 0.81 square mile and the basin slope to be 79.5 feet per mile.

2. From equation 1 or figure 1 determine the mean annual flood $\left(\Omega_{2.33}\right)$ to be $260 \mathrm{cfs}$.

3. Enter figure 2 with the profected degree of development (40 percent impervious and 40 percent storm sewered) and select the ratio $R_{1}$ to be 2.5 .

4. Enter figure 3 with the desired recurrence interval (100 years) and the profected degree of imperviousness (40 percent) and select the ratio $R_{2}$ to be 3.4 .

5. Solution of equation 2 ylelds the desired peak discharge for the 100-year flood for the profected degree of development or

$$
\ell_{100}=R_{1} R_{2} R_{2.33}=2.5 \times 3.4 \times 260=2,200 \mathrm{cfs} \text {. }
$$

\section{IIMITATIONS OF RELATIONS}

The flood-frequency relations presented in this report are highly generalized and should be considered only as an estimate of the true frequency relation for urban areas in Missouri: The relations are considered applicable only to basins with arainage areas in the range of 0.1 to 50 square miles and only for the condition of areally complete development. 
That is, they should not be used for flood-frequency estimates at sites where only a part of the drainage area (upper half, lower half, etc) is expected to be developed.

The following assumptions made in the analysis will affect the accuracy of the relations presented in this report:

1. The mean annual flood for a natural basin in Missouri is adequately expressed by the equation,

$$
\ell_{2.33}=72.3 \mathrm{~A} \cdot 719_{\mathrm{S}} \cdot 330 \text {. }
$$

2. Leopold's diagram for a one-square mile area (fig. 2) is applicable to drainage areas in the range of 0.1 to 50 square miles.

3. Leopold's diagram is applicable to Missouri.

4. The ratio of selected floods to the mean annual flood for natural basins in Missouri is adequately defined by the median ratios of the stations used in the analysis.

5. The 100-percent impervious curve of figure 3 can be defined on the basis of rainfall-frequency relations of the U.S. Weather Service.

6. Intermediate curves of figure 3 can be defined by the interpolation formula proposed by Anderson. 
Desplte the limitations on accuracy the relations presented herein provide a means of estimating desired flood-frequency information for urban areas. These relations should be useful to the urban planner and designer until more detailed and precise studies are completed for the individual urban areas within the state. The relations presented also may be of use in the definition of flood-hazard areas for urban areas in Missouri. 


\section{REFERENCES}

Anderson, D. G., 1968, Effects of urban development on floods In northern Virginia: U.S. Geol. Survey open-flle rept., 39 p., 5 figs.

Carter, R. W., 1961, Magnitude and frequency of floods in suburban areas, in Short papers in the geologic and hydrologic sciences: U.S. Geol. Survey Prof. Paper 424-B, p. B9-B1l.

Epsey, W. H., Morgan, C. W., and Masch, F. D., 1966, Study of some effects of urbanization on storm.runoff from a small watershed: Texas Water Devel. Board Rept. 23, 109 p.

James, I. D., 1965, Using a computer to estimate the effects of urban development on flood peaks: Water Resources Research, v. 1., no. 2, p. 223-234.

Leopold, L. B., 1968, Hydrology for urban land use plannting a guidebook on the hydrologic effects of urban land use: U.S. Geol. Survey Circ. 554,18 p., 8 figs. Martens, I. A., 1968, Flood inundation and effects of urbanization in metropolitan Charlotte, North Carolina: U.S. Geol. Survey Water-Supply Paper, 1591-C.

Sandhaus, E. H., and Skelton, John, 1968, Magnitude and frequency of Missouri floods: Missour1 Geol. Survey and Water Resources, Water Resources Rept. 23, 276 p., 2 figs., 1 pl. 
U.S. Weather Bureau, 1955, Rainfall intensity-duration-frequency curves, U.S. Department of Commerce, Weather Bureau: Tech. Paper No. 25, p. 24, 25.

Witala, S. W., 1961, some aspects of the effect of urban and suburban development upon runoff: U.S. Geol. Survey open-file rept., $28 \mathrm{p}$.

Wilson, K. V., 1966, Flood frequency of streams in Jackson, Mississippi: U.S. Geol. Survey open-file rept., 6 p. 